\title{
Przed Witkacym Szorc na sztorc - nieznane wspomnienie z Zakopanego
}

(opracował Przemysław Pawlak)

Pamiętnik o najbliższej rodzinie, o sobie i o szkole (zeszyt 2, z lat 1928-1939) Jana Szorca (1908-1996) znajduje się w zbiorach rękopiśmiennych Biblioteki Narodowej (sygn. akc. 12100). Został ukończony w 1984 roku i w tym samym roku sprzedany przez autora Bibliotece Narodowej; nigdy nie był publikowany. Do maszynopisu załączono kilka fotografii oraz kartę pocztową, służącą za przykład efektywnego wykorzystania przez autora miejsca na korespondencję za opłatą piętnastu groszy.

Pobyt w Zakopanem dla podleczenia stanu płuc (od lutego do 15 kwietnia 1930 roku) przypadł na „najbardziej urozmaicony” etap życia Jana Szorca, syna Feliksa i Marii z domu Borodzicz, gdy wyrwał się z prowincjonalnego Lublina o „zatęchłej atmosferze". Studia w Warszawie uważał za krok w swym awansie społecznym. Do najistotniejszych impulsów poszerzających horyzonty młodzieniec zaliczył słuchanie wykładów profesorów Uniwersytetu Warszawskiego (wymienieni m.in. Stefan Pieńkowski, Kazimierz Żórawski, Stefan Mazurkiewicz, Samuel Dickstein) i Wyższej Szkoły Handlowej ${ }^{1}$ (Feliks Młynarski, Samuel Adalberg, Bolesław Miklaszewski, Edward Lipiński, Antoni Sujkowski, Henryk Sachs, Eugeniusz Jarra, Władysław Strzelecki, Tadeusz Grodyński, Jan Riemer), „często o europejskiej sławie, uczęszczanie na sztuki teatralne światowego repertuaru w wykonaniu aktorów tej miary, co: Solski, Osterwa, Węgrzyn, Maszyński, Frenkiel, Fertner, Przybyłko-Potocka, Smosarska, 
była jednym z niewielu zainteresowań młodego Jana Szorca. Brał lekcje m.in. u Alfreda Wiłkomirskiego; grał na skrzypcach nieźle, choć nie dość biegle, by aplikować do warszawskiego konserwatorium. Do grona najbliższych przyjaciół Szorca należał demograf i statystyk, prof. Egon Vielrose, z którym już na ostatnim roku studiów opracował zbiór zadań Matematyka finansowa. W 1943 roku żoną Jana została sekretarka Wydziału Karnego Sądu Okręgowego w Lublinie, literatka Helena Platta (1908-1979), wdowa po Zygmuncie Rozwadowskim².

Na dwunastej i trzynastej karcie Pamiętnika znajdujemy relację z czterech krótkich spotkań Jana Szorca ze Stanisławem Ignacym Witkiewiczem w Zakopanem. Na ich przebiegu - jeśli wierzyć autorowi wspomnień - zaważył słuch i muzyczna wrażliwość. Melodyjny gwizd Szorca udobruchał Witkacego, który traktował zarobkowe portretowanie przedstawicielek klasy średniej jako dopust Boży, niemający wiele wspólnego ze sztuką.

Któregoś dnia obie panie zamówily sobie portrety u przebywającego w tym czasie w Zakopanem modnego wówczas i znanego w Polsce literata i portrecisty Stanisława Ignacego Witkiewicza (Witkacy), który w willi swej matki przy ul. Zamojskiego ${ }^{3}$, w okresie zimowym, tj. w pełnym sezonie, prowadził własne atelier portretowe. Wydrukował nawet regulamin firmy portretowej, który właściwie był kpiną i satyrą na wszelkie regulaminy. Czytałem go w mieszanym nastroju, rozgryzając typy portretów, rodzaje narkotyków, jakich w czasie seansu używał. Po pierwszym seansie obie panie wróciły bardzo wzburzone i podekscytowane, gdyż w czasie portretowania nasłuchały się od Witkacego całego szeregu bzdurskich wyrazów i obrzydliwych inpertynencji; proszą mnie, abym im towarzyszył w czasie następnego spotkania, być może będzie się z mężczyzną trochę liczył i hamował w swej elokwencji. Poszedłem z obu paniami. Czekaliśmy około pół godziny, zanim raczył nas zauważyć. W końcu nie zainteresowało go, po co przyszedłem, zapytał tylko, czy to ja przed chwilą na korytarzu gwizdałem główny temat z I części I symfonii Beethovena. Gdy obie panie potwierdziły, że to ja gwizdałem, rozchmurzył się z miejsca i cały czas zachowywał się poprawnie. Przy pożegnaniu prosił mnie, abym przed następnym seansem zagwizdał początek $V$ symfonii Beethovena. Zanim to nastąpiło, przyszedł do naszej willi i przyniósł nam swoją książkę pt. Pożegnanie jesieni. Wręczył tę książkę mnie i powiedział przy wszystkich, że obie panie są za głupie, aby tę książkę mogły przeczytać. A stało się odwrotnie, gdyż książka o różnych warszawskich paniach i zakopiańskich góralach dla 22-letniego młodzieńca była zupełnie nieodpowiednia. Szybko dałem ją obu paniom, które przez tydzień wyrywały ją sobie z rąk do rąk. Zwracając Witkacemu książkę, zastałem go siedzącego przed swoją willą, tępo patrzącego w przestrzeń. Ani mnie, ani pożyczonej książki nie mógł sobie przypomnieć, w końcu wyrwał ją z moich rąk i gdzieś z nią pobiegłł

Panie sportretowane w Firmie Witkacego należały do „inteligencji mieszczańskiej w średnim wieku", grona pensjonariuszy zakwaterowanych na tym samym piętrze willi Walówka co Jan Szorc. Jedną z modelek była najprawdopodobniej starsza od Szorca

2 J. Czachowska, A. Szałagan, Współcześni polscy pisarze i badacze literatury. Słownik biobibliograficzny, t. N-P, Warszawa 1999, s. 400.

${ }^{3}$ Nazwisko Zamojski w nazwie ulicy według pisowni stosowanej w Zakopanem przed 1939 rokiem.

${ }^{4}$ Uwzględniono odręczne poprawki naniesione na maszynopis. Zachowano formy specyficzne dla języka autora („bzdurskich”, „inpertynencji”). Poprawiono oczywistą omyłkę pisarską: „symgonii”.

${ }^{5}$ Willa gazdów Walów u podnóża skoczni narciarskiej, przy ulicy Piłsudskiego; w okresie powojennym nosiła nazwę Złote Serce; w 1946 roku miejsce spotkań członków Organizacji Wewnętrznej (NSZ).

Sztuka Edycji 1/2016 
Lidia Ornatowska, której „dziwne usposobienie” podczas wizyty męża pamiętnikarz opisał w kolejnym akapicie. W przypisie odnotował informację uzyskaną przypadkiem od wielkopolskich uciekinierów podczas Wojny Obronnej 1939 roku: Lidia Ornatowska zmarła w 1931 roku w Poznaniu. Dzięki temu uzupełnieniu i zachowanej ewidencji ludności Poznania możemy być niemal pewni, że chodzi o Lidię z Boruchowskich h. Doliwa, urodzoną 3 lutego 1902 roku w Kamieńcu Podolskim i zmarłą 26 lutego 1931 roku, żonę urzędnika bankowego, Felicjana Ornatowskiego, urodzonego 9 czerwca 1895 roku w Wyżnicy na Bukowinie, syna Jana i Eleonory z Przyłęckich ${ }^{6}$. Nie zachował się ani jeden list Witkacego do żony Jadwigi z zimy i wiosny 1930 roku, inne źródła witkacologiczne nie zawierają wzmianki o Ornatowskiej i Szorcu, nieznane są również losy portretów „obu pań”.

Gdyby nie stopień społecznej reprezentatywności Pamiętnika, można by zlekceważyć i uznać za literackie kurioza bezkrytyczne cytowanie niewybrednych żartów o wykładowcach czy przychylne relacjonowanie chamskiego zachowania rozwydrzonej części polskich studentów w latach trzydziestych. Trudno jednak po lekturze tych buchalteryjnych wspomnień Jana Szorca nie odnieść wrażenia, że tragiczne wydarzenia XX wieku nie przywiodły urzędnika Wydziału Przemysłowego Urzędu Wojewódzkiego w Toruniu, handlowca, wiernego sympatyka Obozu Wielkiej Polski, do głębszej refleksji nad kondycją moralną przeciętnego obywatela II Rzeczypospolitej. Wszak podjął się spisania wspomnień w latach osiemdziesiątych, po upływie półwiecza i śmierci większości ich bohaterów. Nieskrępowany antysemityzm, bezrefleksyjne powielanie stereotypów i akceptacja nepotyzmu rzutują na odbiór Pamiętnika, który stał się dokumentem epoki triumfu (miejmy nadzieję, że poprzedzającego schyłek) drobnomieszczańskiego, nihilistycznego merkantylizmu.

Key Words: Stanisław Ignacy Witkiewicz, Jan Szorc, Pamiętnik o najbliższej rodzinie, o sobie io szkole, manuscripts, Zakopane, editing

Summary: The article presents a fragment of Pamiętnik o najblizszej rodzinie, o sobie i o szkole (Diary about close family, about myself and about school) (issue 2, from 1928-1939) by Jan Szorc, which is stored in the manuscript archives of the National Library. The Diary was finished in 1984 and sold in the same year to the National Library by the author; it was never published. Especially interesting fragments are the ones describing Sztorc's stay in Zakopane, where he went for lung treatment (from 15 April 1930). It was the "most varied" time in Jan Szorc's life, when he broke out of provincial Lublin "with frowsty atmosphere".

On pages 12 and 13 of the Diary one can find a short account of Jan Szorc's meetings with Stanisław Ignacy Witkiewicz in Zakopane. The factor which determined the course of the meetings - if we are to believe the author - was ear for music. Szorc's melodic whistling placated Witkacy, who treated painting portraits of middle-class women for money as a scourge which had little to do with art.

The women painted in Witkacy's Firm belonged to the inmates who lived on the same floor of Walówka Villa. One of the models was probably Lidia Ornatowska (from Boruchowscy family of Doliwa coat of arms), older than Szorc. There are no surviving letters from Witkacy to his wife Jadwiga from winter and spring 1930 , and other sources dedicated to Witkacy do not contain any mentions of Ornatowska and Szorc, the later history of "both ladies" portraits is also unknown. 